\title{
"Vi är egentligen bara siffror" Kontinuitet och förändring i kvinnors arbetslivsberättelser från ett tvätteri
}

\author{
Lena Sohl
}

\begin{abstract}
Dom ökar hastigheten med maskinerna. Dom städar inte ordentligt maskinerna. Jag säger det, dom tänker inte på folk i alla fall. Jag säger, om vi inte jobbar, företaget tjänar inte pengar. [...] Min arbetsledare klagar på mig när jag inte gör siffrorna han bestämmer. [...] Jag sa till honom, "jag jobbar med lön, jag har inte ackordjobb. Du kan öka hastigheten, säga till dom att 'jag vill ha 200'. Du bestämmer, men jag är inte en maskin.”
\end{abstract}

Kate arbetar på ett stort tvätteri. Hon är en av de som jag intervjuat inom ramen för min studie "När fabrikerna inte tystnat: Kvinnliga fabriksarbetares röster", som kapitlet bygger på. ${ }^{1}$ Kate började på tvätteriet för flera decennier sedan, och återkommer till att det blev stora förändringar när tvätteriet gick från att vara landstingsägt till att bli privatägt. Hon säger att arbetstakten har ökat sedan hon började på 1990-talet. Kate berättar att hon säger emot sin arbetsledare när hon får höra att hon inte når målen som andra satt upp för hur mycket hon ska hinna med - Kate säger att hon inte är en maskin. Av hennes berättelse framgår också att hon är medveten om att det är hennes och arbetskamraternas arbete som gör att företaget tjänar pengar.

I studien intervjuade jag kvinnor som arbetade, eller hade arbetat innan de gick i pension, på ett stort tvätteri. ${ }^{2}$ En del av dem hade arbetat där i nästan hela sina arbetsliv. Jag gjorde även arkivstudier av tvätteriets historia på ett regionarkiv. ${ }^{3}$ Tvätteriet ligger på en mindre 
ort och har historiskt haft övervägande kvinnliga anställda. Enligt en jämställdhetsplan från senare delen av 1990-talet var 77 procent av de 168 anställda tvätteriarbetarna kvinnor. ${ }^{4}$ Många som är uppväxta på orten har arbetat på tvätteriet, och flera kvinnor i studien började där genom att sommarjobba. Jag var intresserad av arbetarkvinnors erfarenheter och ett skäl till att jag ville forska om tvätteriet var att jag sedan tidigare kände till kvinnodominansen på arbetsplatsen. Utgångspunkten för studien var att jag ville undersöka kontinuitet och förändring genom arbetslivsberättelser från olika generationer av kvinnor på en mindre ort som dominerats av tvätteriet.

Vid min första kontakt med fackföreningen på tvätteriet 2019 fick jag vetskap om att jämfört med tidigare hade betydligt fler av de anställda kvinnorna migrationsbakgrund, och allt fler män med migrationsbakgrund hade också anställts. Denna tendens ser vi även i andra låglönearbeten, exempelvis inom hemtjänsten, där det tidigare mest arbetat kvinnor med svensk bakgrund (Sörensdotter 2008; Thörnquist 2014). På tvätteriet är nu cirka 60 procent av de anställda män och 40 procent kvinnor, enligt siffror från fackföreningen.

Att personer med migrationsbakgrund rekryterades var inget nytt; tidigare hade arbetare från Finland, forna Jugoslavien och Chile anställts (se Knocke 1986 om rekrytering av kvinnor från dessa länder som arbetskraft i svensk industri). Att tvätteribranschen länge hade önskat anställa migranter framgår bland annat av arkivmaterial. En reseräkning från slutet av 1980-talet gällde en resa till en flyktingförläggning, där representanter från flera landstingstvätterier var med. Syftet med resan uppgavs vara att "försöka rekrytera arbetskraft till tvätterierna" genom att erbjuda "flyktingar arbete och bostad". ${ }^{5}$ Numera framhålls tvätteribranschen som en bransch som erbjuder jobb som är möjliga att få utan att ha utbildning eller längre arbetslivserfarenhet och tvätteriet betonar att de anställda har bakgrund i stora delar av världen. ${ }^{6}$

Fackföreningen har undersökt vilka som har tillsvidareanställning respektive tidsbegränsad anställning och har, baserat på namn, uppskattat om arbetarna har nordisk eller utomnordisk bakgrund. ${ }^{7} \mathrm{Av}$ samtliga anställda hade 2010 drygt 54 procent nordisk bakgrund och drygt 45 procent utomnordisk bakgrund, och 2019 var motsvarande siffror drygt 28 procent respektive drygt 71 procent. Andelen av de tills- 
vidareanställda som hade utomnordisk bakgrund ökade från cirka 42 procent 2010 till cirka 64 procent 2019. Bland personer med tidsbegränsade anställningar ökade andelen med utomnordisk bakgrund än mer: från 55 procent 2010 till 93 procent $2020 .{ }^{8}$ Under perioden $2017-2020$ skedde också en kraftig ökning av tidsbegränsat anställda på tvätteriet som har samordningsnummer. ${ }^{9}$ Fackföreningens uppskattning visar att andelen utomnordiska anställda har ökat, framför allt bland dem med osäkra anställningar (se också Carlén \& de los Reyes, kapitel 2).

Som Joan Acker (2006) belyste när hon introducerade begreppet "ojämlikhetsregim" är alla organisationer präglade av dessa regimer, som består av praktiker, processer, handlingar och betydelser. Regimerna upprätthåller ojämlikheter baserade på klass, kön och föreställningar om ras. Min studie utgår från kvinnors arbetslivsberättelser från en enskild arbetsplats, men de villkor som råder där kan även finnas på andra arbetsplatser. Anställningsvillkoren på tvätteriet speglar i flera avseenden utvecklingen på den svenska arbetsmarknaden för arbetare.

I kapitlet kommer jag att belysa kontinuitet och förändring i arbetsvillkoren på tvätteriet, med utgångspunkt i de kvinnliga tvätteriarbetarnas erfarenheter av klass, rasifiering och exploatering. Teoretiskt vill jag undersöka hur arbetarkvinnors erfarenheter struktureras av klass och rasifieringsprocesser. Frågeställningarna i kapitlet är: Hur resonerar kvinnorna kring sitt arbete och de arbetsvillkor som råder på tvätteriet? Hur beskriver kvinnorna arbetsgivarens praktiker när det gäller anställningar? Hur synliggörs klass och rasifieringsprocesser i kvinnornas berättelser?

I nästa del går jag igenom tidigare forskning, främst svenska kvalitativa arbetsplatsstudier. Därefter beskriver jag de teoretiska utgångspunkterna, som innefattar klass, rasifieringsprocesser och exploatering, samt redogör för hur jag gick tillväga för att göra de intervjuer som studien i huvudsak bygger på. I de följande två avsnitten visar jag hur kvinnorna resonerar kring sitt arbete, kring anställningsvillkoren för olika grupper av arbetare samt kring vilka arbetare som anställs på tvätteriet. Till sist diskuterar jag kvinnornas erfarenheter från tvätteriet mot bakgrund av frågorna om kontinuitet och förändring, med särskilt fokus på exploatering. 


\section{Arbetsplatsstudier: maktförhållanden och olika maktordningar}

Under 1980-talets högkonjunktur minskade andelen tillfälliga anställningar, för att sedan öka kraftigt under 1990-talets lågkonjunktur, en ökning som fortsatte även när konjunkturen vänt uppåt (Håkansson \& Isidorsson 2017. Se även Carlén \& de los Reyes, kapitel 2). Enligt Kristina Håkansson och Tommy Isidorsson (2017) förändrades maktbalansen på den svenska arbetsmarknaden under 1990-talets lågkonjunktur, och arbetsgivarna erbjöd i högre grad än tidigare tillfälliga anställningskontrakt. De strukturella förändringar som har skett sedan 1980-talets privatiseringar och avregleringar har inneburit att arbetet organiseras för att öka "flexibiliteten" (Yazdanpanah 2013). All flexibilitet betyder inte ökad exploatering, däremot öppnar den nya flexibiliteten för större exploateringsmöjligheter. Flexibilisering eller informalisering på arbetsmarknaden är inte något nytt vare sig för arbetarklasskvinnor eller för grupper som rasifieras som de Andra, som Nora Räthzel, Diana Mulinari och Aina Tollefsen (2014) framhållit.

Den svenska arbetarklassen består i dag till stor del av andra än vita män, den grupp som traditionellt ansetts utgöra arbetarklassens kärna. Den "nya svenska arbetarklassen" består, som Diana Mulinari och Anders Neergaard (2004) beskrivit, i hög grad av kvinnor och utlandsfödda. Nära var fjärde arbetare i Sverige år 2016 var utlandsfödd (Neergaard 2018). Utlandsfödda är överrepresenterade i de skikt inom arbetarklassen som har sämst villkor och har exempelvis mindre trygga anställningar än personer födda i Sverige (Behtoui \& Neergaard 2017). Arbetslösheten bland utlandsfödda steg dessutom under perioden 2006-2017, samtidigt som den sjönk för personer födda i Sverige (Kjellberg 2019).

Wuokko Knocke $(1986,1990)$ belyste villkoren för kvinnor med bakgrund i Finland, Grekland, forna Jugoslavien och Chile i arbetaryrken, bland annat inom industrin. I dåtidens termer beskrev hon det som att de utsattes för "det tredubbla strukturella förtrycket - som kvinnor, som arbetare, som invandrare" $(1986,203)$. Hon konstaterade att det inte var möjligt att dra tydliga analytiska gränser mellan de olika formerna av underordning, eftersom de ofta sammansmälte. Även Miriam Glucksmann undersökte i sin klassiska fabriksetnografiska studie Women 
on the line (1982/2009) de olika maktordningar som formade arbetslivet och livet för arbetarkvinnor på en brittisk bilfabrik där många av kvinnorna hade migrationsbakgrund. ${ }^{10}$ Hon visade att kvinnornas liv och möjligheter utanför arbetet var nära sammanlänkade med de hårda villkor som fabriksarbetet innebar. När hon i en artikel 2012 blickade tillbaka på sin tidigare studie såg hon två avgörande förändringar som skett sedan dess. Den första var att migrantarbetare i dagens Storbritannien kommer från hela världen, vilket speglar den globala kapitalismens expansion. Den andra var att könsuppdelningen vid löpande bandet hade upphört - men arbetet utfördes fortfarande av migranter.

Fabriksetnografiska studier var en del av den framväxande arbetslivsforskningen såsom den tog form under industrikapitalismen (se Boréus, Neergaard \& Sohl i kapitel 1), men den expanderande tjänstesektorn har alltmer hamnat i forskningens fokus (se exempelvis Kvist 2006; Mulinari 2007, 2019 samt flera av denna antologis bidrag). Bland de tidigare fabriksetnografiska svenska studierna finns flera undersökningar av Volvos olika företag. Dit hör en av de tidiga och mest kända studierna av arbete i Sverige, antologin Arbetets etniska delning. Studier från en svensk bilfabrik (1994), som gjordes efter den stora arbetskraftsinvandringen under efterkrigstiden. Carl-Ulrik Schierup (1994) fann att på Volvo Torslanda flyttades anställda med svensk bakgrund upp i hierarkin medan de monotona arbetsuppgifterna, där också arbetstakten ökade, övertogs av invandrade arbetare. Knocke $(1994,105)$ framhöll att det finns en klassaspekt $i$ att majoriteten av kvinnorna som invandrat hade lågkvalificerade arbeten och att invandrare på Volvo "i första hand har exploaterats som lönearbetare".

Björn Ohlssons studie Vi som stannade på Volvo (2008) tog sin utgångspunkt $\mathrm{i}$ industriarbetarnas erfarenheter och belyser maktförhållandena mellan ledningen och arbetarna. Ohlsson menade att kapitalets makt är viktigt att beakta i studier av arbetsförhållanden, eftersom denna makt begränsar arbetarnas handlingsutrymme och inflytande över arbetet. Han visade att facket inte hade kunnat påverka förändringar som gjorts under åren, förändringar som ofta inneburit försämringar för arbetarna. Detsamma gäller på tvätteriet, trots att många av arbetarna är fackanslutna. 
En annan Volvostudie är gjord av Nora Räthzel, Diana Mulinari och Aina Tollefsen (2014; se även kapitel 7) och innefattar fyra fabriker. På fabriken i Umeå talade arbetarna om två större förändringar som skett sedan mitten av 1990-talet. Den ena var att företaget inte längre såg arbetarna som centrala för företaget på det sätt som de hade gjort från sent 1970-tal till tidigt 1990-tal. Även inställningen till facket hade ändrats - från att tidigare ha blivit inbjudna till riktiga förhandlingar blev de nu informerade i efterhand, något som känns igen från Ohlssons Volvostudie. Den andra förändringen som arbetarna upplevde var att det fanns en större distans från den lokala fabriksledningens sida. Liknande tendenser framkommer i min studie, där kvinnorna talar om att cheferna inte lyssnar på dem, att det är större distans till cheferna som leder arbetet och även till företagets huvudkontor.

Kvinnors erfarenheter av industriarbete undersökte även Paavo Bergman i Kvinna bland stålmän (2009) som handlar om kvinnor som arbetar vid det mansdominerade stålverket i Luleå. Flera av kvinnorna var fackligt engagerade och hade intresse för fackliga frågor. På grund av förslitningsskador hade en del av dem blivit sjukpensionärer, andra hade fått byta arbetsuppgifter eller gått ner till deltid. Även om kvinnornas kroppar hade tagit stryk av arbetet framhöll de kamratskap och sammanhållning som skäl till att de trivdes på jobbet. Också kvinnorna på tvätteriet sade att kamratskapet och sammanhållningen var avgörande för att de hade stannat på arbetsplatsen och att de hade trivts.

\section{Klass, rasifiering och exploatering}

Karl Marx identifierade i Kapitalet (1867/1970) ägande och exploatering som utmärkande för de klassrelationer som kapitalismens produktionsförhållanden ger upphov till. Huvudmotsättningen inom kapitalismen står enligt Marx mellan dem som äger produktionsmedlen och dem som endast äger sin arbetskraft. Att klassrelationerna av Marx sågs som exploaterande har att göra med produktionsförhållandena, där arbete är det enda som skapar värde och genom att exploatera arbetskraften drar kapitalägarna vinning av det mervärde som lönearbetarna skapar. Med utgångspunkt i Marx värdebegrepp kan vi förstå hur exploatering sker. Det bytesvärde som arbetskraften har innefattar "det tidigare arbete, 
som döljes i arbetskraften" och bruksvärdet "det levande arbete, som den kan prestera" (Marx 1867/1970, 167). Här är det viktigt att hålla isär arbetskraftens värde och det värde som skapas genom arbete. Exploateringen består i att det levande arbete som arbetskraften innefattar producerar mer värde än det bytesvärde som kapitalisterna betalar för (se också Sohl 2014).

Det var i relation till arbete och klass som Robert Miles $(1982,1993)$ började använda begreppet "rasifiering" (se Boréus, Neergaard \& Sohl för en introduktion till begreppet, kapitel 1). Bland annat betonade han att en "rasifierad Andre" (Miles 1993, 44) skapas genom att föreställningar om ras reproduceras, i en process där människor också rasifierar sig själva. Rasifiering kan alltså förstås som en relationell process som inbegriper alla i ett samhälle. Miles menade, som Irene Molina (1997) lyft fram, att det utöver klassfragmentariseringen sker en rasifiering på arbetsmarknaden som bibehåller stratifieringen av arbetskraften. Hur rasistiska logiker samverkar med klassexploateringen inom kapitalistiska produktionsförhållanden har analyserats av Edna Bonacich (1972). Bonacich, Sabrina Alimahomed och Jake B. Wilson (2008, 343) menar att en anledning till att rasifiering sker på arbetsmarknaden är att vissa grupper lyckas "exploatera underordnade rasifierade gruppers lönearbete" (min översättning). De skiljer mellan primär och sekundär rasifiering. Den primära grundar sig i vita kapitalisters exploatering av arbetare som rasifieras som de Andra, vilka de kan exploatera mer än vita arbetare. Den sekundära uppkommer bland vita arbetare och riktar sig mot arbetare som rasifieras som de Andra. På grund av exploateringen av arbetare som rasifieras som de Andra är vita arbetare rädda för att bli undanträngda och kan därför medverka i arbetsgivarens överexploatering av arbetare som rasifieras som de Andra (Bonacich, Alimahomed \& Wilson 2008). Detta innebär att arbetarkollektivet splittras till följd av kapitalisternas primära rasifiering (se Svensson 2019).

Begreppet "exploaterande rasism" (exploitative racism) har introducerats av Diana Mulinari och Anders Neergaard $(2017,92)$ för att förklara hur en exploaterbar rasifierad arbetskraft skapas av dem som befinner sig i privilegierade klasspositioner och har möjlighet att exploatera andra, genom direkt eller indirekt rasism. ${ }^{11}$ Den exploaterande rasismen har blivit en normalitet och har förstärkts under nyliberalismen. Denna 
typ av rasism synliggörs sällan i klassteoretiska termer, till skillnad från arbetarklassens rasism, som ofta förklaras utifrån klassposition (se exempelvis Roediger 1991/2007). Tidigare klassteoretiska förklaringar till rasism har, som Mikael Svensson (2019) påpekat, ofta handlat om arbetarklassen. Marxistisk teori ser arbetarklassens rädsla att mista sitt arbete eller få försämrade arbetsförhållanden som viktiga orsaker till exempelvis rasistiska praktiker gentemot utländsk arbetskraft. Mot samma teoretiska bakgrund går det att förstå hur kapitalister istället kan tjäna på att anställa utländsk arbetskraft: det gör att de kan hålla lönerna nere som en del av exploateringen av arbetare.

Det är den primära rasifieringen och den exploaterande rasismen som jag främst är intresserad av i det här kapitlet. Det innebär inte att det inte finns uttryck för sekundär rasifiering eller exkluderande rasism i mitt intervjumaterial, men dessa processer och praktiker är inte främst i fokus här. En anledning att rikta blicken mot den exploaterande rasismen och den primära rasifieringen är att den är mindre utforskad än den exkluderande rasismen och den sekundära rasifieringen.

\section{Att intervjua kvinnor som är tvätteriarbetare}

Inom ramen för studien "När fabrikerna inte tystnat: Kvinnliga fabriksarbetares röster" har jag genomfört tolv individuella semi-strukturerade intervjuer som kapitlet baseras på..$^{12}$ Intervjuerna varade i mellan en och tre timmar. De kvinnor jag intervjuade har arbetat på tvätteriet mellan några år och flera decennier. ${ }^{13}$ Två av kvinnorna är nu pensionärer. Den yngsta intervjupersonen är född på 1990-talet och den äldsta på 1930-talet. Av intervjupersonerna är sex födda i Sverige, liksom deras föräldrar, och sex i andra länder: tre i ett annat nordiskt land, en i ett sydeuropeiskt land, en i ett sydamerikanskt land, en i ett afrikanskt land. ${ }^{14}$ I relation till frågorna om kontinuitet och förändring är tidpunkten för migrationen av betydelse: de tre kvinnor som har nordisk bakgrund kom alla till Sverige under 1960-talet, två av dem i vuxen ålder och en som barn. Av de andra tre utlandsfödda kom en kvinna till Sverige på 1990-talet och två på 2010-talet. Urvalet är inte representativt när det gäller hur fördelningen mellan utlands- och svenskfödda ser ut på tvätteriet $i$ dag, och avser inte heller att vara det. Mitt syfte är inte att enbart 
studera den nuvarande situationen, utan kontinuitet och förändring i kvinnornas arbetsliv på tvätteriet.

Intervjufrågorna handlade främst om kvinnornas arbetsvillkor, men även om livet utanför arbetet. Intervjuerna berörde teman som kvinnornas tidigare och nuvarande arbetsliv samt villkoren på arbetsplatsen (bland annat fackligt engagemang, kontakten med arbetskamraterna, vad kvinnorna skulle vilja förändra). ${ }^{15} \mathrm{Jag}$ ställde frågor som rörde om och hur kvinnorna identifierade sig klassmässigt, hur villkoren för män och kvinnor var på arbetsplatsen och, liksom Schierup (1994), hur relationerna på arbetsplatsen var mellan anställda med olika födelseland.

Fackanslutningen på företaget är hög, vilket är anmärkningsvärt med tanke på att många har tillfälliga anställningar. Möjliga anledningar till detta kan vara att arbetsplatsen är relativt stor med många anställda och att tvätteriet har en egen fackklubb. Arbetsgivaren har flera gånger fått betala skadestånd efter att frågor gått till lokala eller centrala förhandlingar, vilket gör att klubben har budget för att erbjuda en hel del aktiviteter för medlemmarna. Att facket organiserar en majoritet av de anställda speglas i intervjumaterialet, där alla utom en är eller har varit (de som är pensionerade) med i facket. Flera av kvinnorna är eller har varit fackligt aktiva, vilket gör att de har erfarenhet av fackligt vardagsarbete. Av hänsyn till anonymiteten anger jag inte vilka kvinnor som arbetar fackligt idag, utan skriver genomgående att de har arbetat fackligt.

Några intervjupersoner rekryterade jag med hjälp av en fackföreningsrepresentant, men det visade sig vara svårt att nå intervjupersoner den vägen. Genom fackföreningen fick jag tillåtelse av företaget att själv komma till arbetsplatsen. Vid det första tillfället gick jag runt tillsammans med fackföreningsrepresentanten på tvätteriets olika avdelningar för att prata med kvinnorna, sedan fick jag också möjlighet att gå runt på egen hand. En del av intervjupersonerna rekryterade jag vid dessa besök, andra hörde talas om projektet via fackföreningen eller via arbetskamrater som redan blivit intervjuade. Andra intervjupersoner fick jag när jag var på plats i samhället och genom kontakter jag hade i samhället sedan tidigare.

Alla intervjuade som idag arbetar på tvätteriet har fast anställning, men Sara och Leila har tidigare haft tillfälliga kontrakt under länge 
perioder. Det var svårt att få kvinnor med tillfälliga anställningar att ställa upp för intervjuer, så berättelserna om tillfälliga anställningar kommer från kvinnor som idag har fasta anställningar. Många med utländsk bakgrund hör till dem som har tillfälliga anställningar, vilket kan vara en förklaring till att det var svårt att få kvinnor med utländsk bakgrund att ställa upp. När jag gått runt på tvätteriet har jag dock haft samtal med kvinnor som har tillfälliga anställningar, och som arbetat på tvätteriet en kortare tid. En kvinna som jag pratade med i matsalen sade att hon inte hade jobbat där tillräckligt länge för att kunna uttala sig. Utifrån de samtalen tror jag att en förklaring till att de med tillfälliga anställningar inte ville delta i studien var att de inte känner sig bekväma med att tala om villkoren på en arbetsplats där de inte har en stabil position. Under tiden som studien pågått har det förekommit att små förseelser har gjort att kontrakten inte förnyats för personer som har haft tillfälliga anställningar, vilket också kan ha påverkat kvinnornas villighet att ställa upp. Att jag, som enbart talar svenska och engelska, har varit begränsad när det gäller att prata med kvinnor som talar andra språk än dessa kan också ha haft betydelse. ${ }^{16}$

Det har också varit svårt att få kvinnor som är födda i Sverige att ställa upp, liksom kvinnor med tillsvidareanställningar. Flera av dem som jag har pratat med när jag varit på plats på tvätteriet har i ett senare skede tackat nej till att bli intervjuade. Även en del av kvinnorna som ingår i studien och har fasta anställningar har varit tveksamma till att ställa upp på en intervju. En kvinna sade vid intervjutillfället att hon oroat sig för att det skulle kunna få negativa konsekvenser för henne på arbetsplatsen om hon lät sig intervjuas, om hon till exempel var kritisk mot företaget. Hon hade frågat en av sina chefer hur han ställde sig till att de anställda intervjuades för forskningsprojektet och fått svaret att det inte skulle medföra några negativa konsekvenser. Efter att ha fått veta det tackade hon ja.

\section{"Ibland glömmer dom att vi är bara människor"}

Kvinnornas erfarenheter av arbetet på tvätteriet spänner över flera decennier, vilket gör att de har djupgående kunskaper både om vad arbetet innebär och om arbetsvillkoren - den kontinuitet som finns 
och de förändringar som skett. Det finns ett motstånd mot de förhållanden som råder på arbetsplatsen, som tydligt artikuleras i kvinnornas berättelser. Att arbetare är kritiska till arbetsorganisation, arbetsförhållanden, chefer, enskilda beslut och personalpolitik framgår i tidigare studier (Ohlsson 2008; Schierup 1994). De Volvoarbetare som Ohlsson $(2008,225)$ intervjuade hade erfarit "den underordnade ställning de har på arbetsplatsen" många gånger under sitt arbetsliv, något som också artikuleras av kvinnorna i min studie.

Kvinnorna återkommer, i sina berättelser om arbetet och villkoren, till att de trivs på arbetsplatsen och att det har varit roligt att arbeta på tvätteriet, samtidigt som deras berättelser är starkt präglade av beskrivningar av hårdnande arbetsvillkor: arbetet är stressigare, arbetsgivaren övervakar dem och lyssnar inte på dem. Gunhild, Maria och Johanna har jobbat på tvätteriet i decennier. När jag frågar Gunhild vad hon tycker om sitt jobb svarar hon: "Det är kul." Maria, som nu är pensionär, säger att hon har trivts på tvätteriet. Hon har trivts med människorna som jobbat där, med sammanhållningen och med själva jobbet. Johanna uttrycker sig på ett liknande sätt: "Med arbetet har jag trivts." Men när hon svarar på min fråga om vad som är det bästa med jobbet beskriver hon en förändring:

Johanna: Vi har inte lika roligt som vi har haft förr, då var det mer skratt och stoj och ... Det var ett helt annat sätt.

Lena: Mm. Vad har det att göra med då? Alltså, att det var roligare? Är det det där att ni inte känner varandra lika bra?

Johanna: Nej, vi får ju inte prata lika mycket längre [skratt]. [...] $\mathrm{Nu}$ är det bara produktionen som gäller, nu ska man bara producera ...

I likhet med Johanna gör flera av kvinnorna distinktioner mellan ett då och ett nu, när det gäller hur stämningen är på arbetsplatsen. Att de har trivts på arbetsplatsen och tyckt att det har varit roligt att gå till jobbet är något som framkommer i flera av intervjuerna. I beskrivningarna av de hårdnande villkoren återkommer kvinnorna till att de inte längre får prata med varandra när de vill utan att bli tillsagda av arbetsledare. Kate, som har arbetat i decennier på tvätteriet, tar upp att arbetsgivaren har infört en rad förbud för de anställda: "förbjuder att 
prata, förbjuder telefon, allt är förbjudet [skratt]”. Att både Johanna och Kate skrattar när de berättar om att de inte längre får prata så som de gjorde tidigare kan ses som ett sätt att distansera sig från, och kanske i viss mån tona ner, den ökade makt som arbetsgivaren utövar över kvinnornas arbetsvillkor. Förbudet att prata med arbetskamraterna kan, förutom som en del i övervakningen av arbetarna, också ses som en exploaterande praktik, i den meningen att det handlar om att få ut så mycket arbetstid som möjligt från arbetarna.

Kvinnorna pratar framför allt om att det har skett en förändring när det gäller att produktionen och produktiviteten har blivit allt viktigare för företaget. Gunhild, som har varit fackligt engagerad, säger att förskjutningen av maktrelationerna har att göra med att tvätteriet först privatiserades och sedan började drivas som en industri, och att produktiviteten då hamnade i fokus. En annan förändring som Gunhild belyser är att fackförbundet på arbetsplatsen har gått från att tillhöra Kommunalarbetarförbundet till att tillhöra IF Metall, en förändring som flera av kvinnorna beskriver som en försvagning av fackets inflytande. Gunhild beskriver hur hon upplevde övergången till att tvätteriet började drivas som en privat industri:

Där blev det ledningsstyrt. Inte för att vi på golvet någonsin har styrt Tvätten men alltså, man brydde sig mer, man kunde följa upp och "ja, men det är klart att ni ska ha en sån”. Då fanns pengar, det var liksom ingen tvekan.

Det Gunhild berättar om kan ses som en del av den övergripande förändring på arbetsplatsen som innebär att detaljstyrningen har ökat. Det avspeglas i villkoren för kvinnor i arbetarklassen under de senaste decennierna: 1993/1995 kunde 61 procent av arbetarkvinnorna inte bestämma när de skulle utföra olika arbetsuppgifter, 2013/2015 var andelen 71 procent (Larsdotter 2017, 28).

Det vore lätt att tolka Gunhilds och Johannas uttalanden ovan som nostalgiska berättelser om en dåtid med en mindre exploaterande kapitalistisk produktion som ställs mot nuets mer oförblommerade exploatering. Men utifrån kvinnornas berättelser skulle jag inte säga att utsagorna främst handlar om en längtan till något som var bättre 
förr. Snarare kan berättelserna ses som ett uttryck för kvinnornas medvetenhet om den maktförskjutning som har skett på tvätteriet, till arbetarnas nackdel. Både Gunhilds och Johannas berättelser går att förstå som beskrivningar av en kamp om tid och mervärde.

Leila och Sara är de intervjupersoner som har jobbat kortast tid på tvätteriet, och de har enbart erfarenhet av att arbeta där under den tid då tvätteriet drivits som en privat industri. Leila tar upp en dimension som återkommer i flera av intervjuerna, och som rör de mål för arbetarnas produktionstakt som företaget har satt upp:

Vi har mål som man ska nå, så det betyder att du kan inte ... Du behöver alltid kämpa på och jobba hårt för att du ska komma till det här målet. [...] Man är inte en maskin, man kan inte varje dag jobba med samma kraft.

Leila uttrycker sig på ett liknande sätt som Kate i citatet som inledde kapitlet: de motsätter sig båda att betraktas som maskiner, men deras sätt att uttrycka sig implicerar att arbetsvillkoren förutsätter att de är det. I Leilas beskrivning framstår arbetet som en kamp, hon talar om att "kämpa på" och att "jobba hårt", även om hon också betonar att det inte är möjligt att göra det varje dag, trots att produktionstakten egentligen kräver det. På ett liknande sätt som Leila beskriver Sara att produktiviteten och målen som arbetarna förväntas uppnå är det viktigaste för företaget:

Och dom vill inte att man ska stanna ... För man kan ju stanna bandet. Men då förlorar man på produktionen och det är ju ... Siffror är det viktigaste för dom. Ibland glömmer dom att vi är bara människor och vi kan ha dåliga dagar och vi kan ha ... Att man har extra ont och man inte är lika snabb. Men det känns som att dom ibland glömmer det, att målet måste nås.

Det Sara talar om när hon säger att företaget inte vill att arbetarna ska stanna det löpande bandet kan ses som ett bristande inflytande över arbetssituationen. I Saras berättelse finns tre begrepp som återkommer även i intervjuerna med andra kvinnor: "produktion", "siffor" och 
"mål". Mot dessa tre ställer Sara sin utsaga "vi är bara människor", en betoning av ett annat perspektiv än det som är företagets: företaget glömmer bort arbetarnas mänsklighet. Hon gör en distinktion mellan företaget ("dom") och arbetarna ("vi"), som kan tolkas som att de har olika intressen.

Saras berättelse återspeglar villkoren i arbetslivet för arbetarklassen i stort: arbetarklassen är den klass som har minst inflytande över sin arbetssituation (Berglund 2008). Arbetsgivarnas makt och kontroll på arbetsplatserna har intensifierats sedan 1990-talet, bland annat i form av målstyrning (Hörnqvist 2019). I tidigare forskning har andra arbetarkvinnor uttryckt liknande erfarenheter som Sara gör, som när kvinnorna på Volvo Torslanda tyckte att företaget behandlade dem som "kuggar i maskineriet, som utbytbara produktionsfaktorer" (Knocke 1994, 105).

Kvinnorna är kritiska till vad de uppfattar som företagets ensidiga fokus på siffror, vilket de ställer mot den mänskliga arbetskraft de själva bidrar med för att siffrorna ska uppnås. Av kvinnornas berättelser framgår att de motsätter sig att objektifieras i arbetet och att berövas sitt agentskap. Ett exempel kommer från intervjun med Gunhild, som säger: "Du ska ju inte tro att jag är en person, utan jag är 7,6 timmar." Hon återkommer flera gånger till att hon tycker att det är siffror som styr på tvätteriet, som när hon beskriver arbetarnas roll: "Vi är ju egentligen bara siffror." Hon säger att ledningen bara ser siffror, men inte personen som utför siffrorna åt dem. Gunhild kontrasterar det mot hur det var när hon började på tvätteriet, innan det hade privatiserats. Då kunde arbetarna när de hade manglat klart för dagen själva bestämma att de skulle gå hem, men det har de inte makt att bestämma över längre. Kvinnornas berättelser om att produktion och produktivitet har blivit allt viktigare för företaget och att arbetarna reduceras till siffror, till det mervärde de skapar för företaget, kan förstås som erfarenheter av exploatering.

När jag intervjuar Molly frågar jag om hon känner igen sig i Gunhilds beskrivning. Hon instämmer i att det har skett en förändring i synen på de anställda, som yttrar sig i både arbetstempot och övervakningen:

Dom som står där nere och galgar [hänger upp plagg] ... Jag har gjort det någon gång men jag säger att dom skulle ha Nobelpriset. Stått där 
i tjugo år, beundransvärt alltså, och galga då trehundra i timmen och så titta på den där teveapparaten, är den röd eller är den grön? Men grannens är grön och min är röd, vad ska jag göra liksom?

I vissa arbetsmoment övervakas de anställda på tvätteriet på ett sätt som de inte gjorde tidigare. Flera av kvinnorna tar upp den skärm som Molly kallar teveapparaten, som finns utplacerad vid galgningen. Skärmen visar hur det går för varje arbetare på de olika galgstationerna, men också hur mycket gruppen galgat totalt och vad det uppsatta målet är. Den lyser rött eller grönt beroende på om arbetarna har nått de uppsatta målen eller inte. När Molly säger att de som utför det monotona, stressiga och övervakade arbetet med galgningen borde belönas med ett Nobelpris är det ett synliggörande av ett arbete som, utöver övervakningen, annars sällan blir synligt.

När jag frågar Molly, som har varit fackligt engagerad, vad facket har gjort när det gäller övervakningen på arbetsplatsen säger hon: ”Nej, men alltså vi har väl försökt hela tiden att opponera oss mot saker som de ska försöka göra som blir mycket sämre.” På tvätteriet är det tydligt att även om arbetarna i hög grad är fackligt anslutna och flera av intervjupersonerna är eller har varit fackligt aktiva har arbetsgivaren ändå kunnat genomföra förändringar som kvinnorna är kritiska till. Det gäller inte minst övervakningen och de arbetsvillkor som kvinnorna menar reducerar dem till maskiner och siffror. Det kan ses mot bakgrund av vad Räthzel, Mulinari och Tollefsen (2014) har tagit upp: att den höga organisationsgraden präglar självbilden hos svenska fackföreningar, men att vara många medlemmar betyder inte att styrkan hos arbetarna är likvärdig med den som kapitalet har. Erfarenheten av att inte bli lyssnade på, trots att de återkommande använder sina röster och säger ifrån, både som en del av sitt fackliga arbete och som enskilda anställda, går igen i kvinnornas arbetslivsberättelser.

I kvinnornas berättelser framträder också en allt tydligare motsättning mellan arbetarna och de villkor som råder för produktionen. I kvinnornas erfarenheter finns tydliga uttryck för klassexploatering, som när de talar om att de förväntas producera enligt mål som ledningen satt upp och att det som styr produktionen är siffror. Att kvinnornas mänsklighet åsidosätts synliggörs genom att de talar om hur de betraktas 
som siffror, som när Gunhild säger att hon inte längre ses som en person när hon kliver in på tvätteriet, utan som sin arbetstid på 7,6 timmar. Exploateringen av kvinnorna, av arbetets tid och mervärde, synliggörs i kvinnornas berättelser. Men där syns också deras motstånd, som när Kate och Leila betonar att de inte är maskiner, utan människor.

\section{Vilka arbetare och vilka villkor? Distinktioner mellan olika arbetare}

Den kapitalistiska produktionen bygger på konstruerade distinktioner mellan människor, vilka grundar sig i bland annat rasifieringsprocesser (Sahraoui, kapitel 6). Kapitalismens nya former av exploatering har fått effekter för hur arbetet organiseras, enligt Paulina de los Reyes och Diana Mulinari (2005), som visar att den normalisering av instabiliteten som skett inte är jämnt fördelad mellan olika grupper. Immanuel Wallerstein (1997/2004, 56) betraktar kapitalismen som ett system som är med och skapar rasism: "Etnifieringen av arbetskraften existerar för att det ska vara möjligt att ge mycket låga löner åt hela segment av arbetskraften." Som Boréus, Neergaard och Sohl (kapitel 1) belyser uppstår segment på arbetsmarknaden för invandrade arbetare, och det möjliggör överexploatering eftersom dessa arbetare har svårare än andra att hävda rättigheter som andra har på arbetsmarknaden.

Kvinnorna jag intervjuade gör inte distinktioner mellan olika grupper när de talar om detaljstyrning och övervakning eller när det gäller synen på arbetare som maskiner eller siffror, som jag skrev om ovan. I dessa delar av kvinnornas berättelser framstår alla arbetare på tvätteriet som exploaterade. När det däremot gäller vilka arbetare som anställs och på vilka kontrakt, samt i viss mån vilka föreställningar arbetsgivaren har om människors arbetsförmåga, framkommer distinktioner; vissa grupper av arbetare framställs som överexploaterade.

En av de intervjupersoner som arbetat längst tid på tvätteriet är Maria, som kom till Sverige på 1960-talet. Hon berättar om sin första arbetsdag på tvätteriet:

Ja, jag kunde inte svenska, jag blev kastad till sorteringen på Tvätten. Och vad ska man göra? Man kunde inte säga ja eller nej, bara jobba, 
och då var det ackord på sorteringsbandet. Och det är bara jobba, ingenting annat. Och sen tänkte jag alltid så här att "nej, jäklar anamma, nu ska jag börja prata svenska”.

Maria säger att sorteringen, den avdelning där smutstvätten tas om hand vid ett löpande band, var det "skitigaste" stället på tvätteriet och den tyngsta avdelningen. Hon använder ordet "kastad" när hon beskriver hur hon hamnade på sorteringen. Ohlsson $(2008,226)$ menar att arbetet vid ett löpande band "tvingar dem som står där att arbeta med en viss hastighet och på ett förutbestämt vis", vilket är ett av de tydligaste exemplen på "vardaglig regelbunden underordning i arbetslivet". På ett liknande sätt berättar Kate om när hon började på sorteringen på 1990-talet. Hon säger att "dom skickade" dit henne och nämner att hon då inte kunde tala svenska. I Marias beskrivning är språket kopplat till att ha makt över sin arbetssituation. Att hon inte kunde svenska innebar att hon inte hade möjlighet att säga sin mening, utan hon blev hänvisad till att arbeta. På sorteringen arbetade många som kom från samma land som hon själv, så dem kunde hon prata med.

Maria berättar vidare att den dåvarande chefen för tvätteriet gärna ville anställa personer som kom från samma land som hon själv: "han tyckte att dom var bra". Etniska stereotyper behöver inte ha ett negativt innehåll (se Schierup, Paulson \& Ålund 1994). Knocke (1994) visar att etniska skiktningar samt etniskt baserade fördomar försvårade för vissa grupper av arbetare (jugoslaviska män), medan den stereotypa bilden av finska män som tysta och hårt arbetande inte hade samma negativa effekter. Jag menar att sådana stereotyper och fördomar ändå kan bygga på rasifierade föreställningar om vilka arbetare som platsar var i organisationens hierarki och vilken arbetsförmåga de har. Tidigare har Svensson $(2019,192)$ visat att ett uttryck för primär rasifiering är att "invandrarungdomar" konstrueras som en grupp som "särskilt exploaterande organisationspraktiker" kan riktas emot när det gäller vilka tjänster och villkor de erbjuds.

Molly, som är född i Sverige och har jobbat länge på tvätteriet, beskriver dagens situation på arbetsplatsen på ett liknande sätt som Maria, när det gäller att cheferna gärna anställer personer med utländsk bakgrund med hänvisning till deras arbetsförmåga: "Nej, men man har hört att 
cheferna har sagt att vi anställer hellre utlänningar för att de är mycket duktigare att arbeta." Hon fortsätter:

Jag har hört det, sen så är det inte så att jag går i korridoren varje dag, men jag menar, vi märker ju själva. Men det är klart att dom suger ju ut det bästa av den här personen då som kommer och jobbar här i 11 månader och 29 dagar. Och då har han gjort sitt bästa för att han tror att han ska få fortsätta jobba.

Likt Maria säger Molly att cheferna gör distinktioner mellan arbetare och att de har en föreställning om att människor med utländsk bakgrund har förmågan att arbeta hårdare än personer med svensk bakgrund. Molly talar om att tvätteriet suger ut de arbetare med utländsk bakgrund som erbjuds tillfälliga anställningar. Marias och Mollys berättelser belyser en kontinuitet $\mathrm{i}$ chefernas syn på personer med utländsk bakgrund som hårt arbetande, enligt vad kvinnorna uppfattar och förmedlar. Det finns dock en avgörande skillnad i deras berättelser. Maria säger att hon, i likhet med andra kvinnor jag intervjuat som anställdes under 1960- och 1990-talen, fick fast anställning direkt. Det är en kontrast till den situation som Molly beskriver idag, när det i regel är tillfälliga anställningar som erbjuds. Kontinuiteten som går att spåra genom deras berättelser består i en uttalad vilja från arbetsgivaren att anställa arbetare med utländsk bakgrund, samt föreställningar om denna arbetskrafts arbetsförmåga. Förändringen består i vilka anställningsformer dessa arbetare erbjuds.

Leila, som har universitetsutbildning och kom till Sverige under 2010talet, berättar att hon sökte ett "kontorsjobb" när hon först kontaktade tvätteriet, men fick veta att företaget inte hade några sådana tjänster på orten. Hon tackade först nej till att arbeta där, men efter att ha sökt jobb som motsvarade hennes utbildning utan att bli erbjuden något började hon arbeta på tvätteriet, i vad hon kallar ett "kroppsjobb". "Det betyder du ska inte prata mycket så du kan bara köra maskin", säger Leila. Hon var vikarie under två års tid och säger att hon i början fick anställning för några dagar eller en vecka, sedan en månad och därefter fast: "Men nu jag vet inte, nu det blir annorlunda. [...] Vikarierna, de jobbar bara elva månader." Leila kontrasterar sin egen situation, att gå från olika kortare och längre tillfälliga anställningar till fast, mot 
villkoren som erbjuds idag. Liksom flera andra kvinnor talar hon om de elvamånaderskontrakt som vikarierna erbjuds, och som i regel inte övergår i fasta anställningar.

Sara kom också till Sverige på 2010-talet. Hon hade ett elvamånaderskontrakt och i likhet med Leila fick hon en fast anställning senare. Båda talar om arbetskamrater som inte erbjuds fasta anställningar efter att deras vikariat har tagit slut. Sara beskriver hur hon ser på arbetsgivarens anställningspraktiker, och nämner kvinnor med utländsk bakgrund:

Och för kvinnor, om man tänker att vi är många utlänningar, dom kan inte språket och Tvätten utnyttjar dom för att dom kan inte sina rättigheter, och då är det lättare.

Sara beskriver att kvinnor med utländsk bakgrund - dit hon räknar sig själv och hon använder ordet "vi" - kan utnyttjas av arbetsgivaren. Hon talar också om "de" som inte, till skillnad från henne själv, talar svenska och som hon menar inte känner till sina rättigheter. I Saras resonemang framstår (vissa) kvinnor med utländsk bakgrund som möjliga för arbetsgivaren att överexploatera. Hon är kritisk till de tillfälliga anställningarna eftersom hon menar att människor ställer upp och jobbar övertid på övertid, för låg lön, när företaget behöver arbetskraft: "Och inget fast till slut, man ger sitt allt och så får man inget tillbaka av företaget, alltså, det är fel."

Ett annat exempel på distinktioner som kvinnorna gör mellan olika grupper av arbetare kommer från intervjun med Gunhild, som har jobbat på tvätteriet i flera decennier. Hon pratar om de tidsbegränsade anställningarna och beskriver vilka arbetare som företaget vill anställa, som hon ser det: "Alltså, nu är vi nästan så att de tar dem från Arlanda och de har knappt ett samordningsnummer, så illa är det." Hon lägger till att det är hennes personliga åsikt att "arbetsgivaren väljer att nyttja dem för att de är en svagare grupp". Att utrikesfödda som befunnit sig i landet under kort tid ofta får anställning i låglöneyrken har belysts i tidigare forskning (se exempelvis Storm 2018). I likhet med Sara, som tycker det är fel att företaget anställer personer med utländsk bakgrund på tidsbegränsade anställningar, uttrycker Gunhild kritik mot att företaget drar nytta av vad hon kallar "en svagare grupp". 
Detta visas även i hennes, lite tillspetsade, beskrivning av att företaget "nästan" anställer personer så fort de satt sin fot på svensk mark. Samtidigt talar Gunhild i termer av "vi" när hon beskriver de anställningspraktiker som arbetsgivaren har, trots att hon är tydligt kritisk till dessa praktiker. Hon distanserar sig dock från företaget genom att säga "de tar dem från Arlanda", men hon talar om människorna som hon menar att arbetsgivaren vill anställa som "dem". Som Paulina de los Reyes och Masoud Kamali (2005) visat reproduceras de socialt konstruerade kategorierna "vi" och "de" genom att "invandrarskap" konstrueras i motsats till en föreställd "svenskhet". Samtidigt som Gunhild uttrycker kritik mot det hon ser som exploatering, gör hon en uppdelning som pekar mot att hon inte ser dessa arbetare som del av samma arbetarkollektiv som hon själv identifierar sig med.

De arbetsvillkor som förenar många av dem som har arbetarklasspositioner på arbetsmarknaden skulle kunna leda till att en solidaritet byggs mellan olika delar av arbetarklassen. Samtidigt kan diskrimineringen på arbetsmarknaden av personer som rasifieras som de Andra leda till att det skapas en klyfta mellan dem och personer som betraktas som svenskar (Neergaard 2018). Neergaard skriver (2018, 23): "effekterna av diskriminering riskerar att skapa olika erfarenheter av klass och därmed olika klassidentiteter, vilket försvårar för fackföreningsrörelsen i formerandet av ett kollektivt 'vi arbetare'." I flera av kvinnornas beskrivningar från tvätteriet framstår detta inte bara som en risk, utan som ett faktum.

Kvinnornas berättelser om arbetsgivarens praktiker kan ses som beskrivningar av en exploaterande rasism (Mulinari \& Neergaard 2017) som grundar sig i primär rasifiering (Bonacich, Alimahomed \& Wilson 2008). I Marias och Mollys berättelser framstår personer med utländsk bakgrund som attraktiv arbetskraft på grund av arbetsgivarens föreställningar om deras arbetsförmåga. Sara talar om andra skäl till att företaget vill anställda personer med utländsk bakgrund och nämner kvinnor som hon menar inte känner till sina rättigheter och de ses som "flexibel" arbetskraft som arbetar övertid för låga löner. 


\section{Exploatering, kontinuitet och förändring}

Arbetare är, menar Räthzel, Mulinari och Tollefsen (2014), den grupp som mest direkt påverkas av de nyliberala kapitalistiska produktionsstrategierna, samtidigt som de sällan blir lyssnade på. Genom att utgå från kvinnornas arbetslivsberättelser från tvätteriet har jag i det här kapitlet belyst kontinuitet och förändring i arbetsvillkoren, men också i den exploatering som framkommer i kvinnornas beskrivningar. Av deras berättelser framgår att förbud och övervakning, att bli berövad sitt agentskap genom att betraktas som en siffra och att styras av mål som arbetsgivaren har satt upp är något som gäller arbetare som grupp på tvätteriet. Dessa villkor kan beskrivas som exploaterande i den meningen att de rör kamp om mervärde och arbetarnas tid, där företaget och arbetarna har olika intressen. Kvinnorna är kritiska till arbetsgivarens övervakning och de arbetsvillkor som har gjort arbetet hårdare och mer detaljstyrt, men också till den förskjutning när det gäller inflytande som de menar har skett under åren som de arbetat på tvätteriet. I kvinnornas berättelser återkommer en kritisk syn på hur chefer och arbetsledning agerar, exempelvis att arbetarna inte ses som människor, utan som maskiner.

Kvinnorna framhåller arbetare med utländsk bakgrund som en grupp som är mer utsatt och som därför kan bli föremål för överexploatering. Arbetsgivarens praktiker, så som de framställs i kvinnornas berättelser, när det gäller arbetare med utländsk bakgrund kan förstås som uttryck för en exploaterande rasism, som har sin grund i primär rasifiering. I kvinnornas berättelser visar sig de olika uttryck som den exploaterande rasismen, som riktas mot arbetare med utländsk bakgrund, tar sig. En av dess grunder är föreställningar om att arbetare med utländsk bakgrund är hårt arbetande som mot låg lön kommer att producera mer värde än vad företaget betalar för. Att producera mer värde för företaget än vad man får betalt för ligger i arbetets natur, men arbetare med utländsk bakgrund framställs som att de kan vara ännu mer lönsamma för arbetsgivaren. En förändring som kvinnornas berättelser belyser är att arbetare med utländsk bakgrund numera ofta anställs på tillfälliga kontrakt. 
Kvinnorna beskriver villkor som för samman arbetarna på tvätteriet, men också villkor som splittrar. Det finns en spänning i intervjuerna mellan upplevelser av att vara gemensamt exploaterade och uppdelningar inom gruppen arbetare baserat på primär rasifiering, där arbetarna på tvätteriet splittras i olika grupper. Av kvinnornas berättelser framgår det att arbetare som grupp exploateras på tvätteriet, och att primär rasifiering från arbetsgivarens sida gör att vissa arbetare placeras i delar av produktionen som är "skitiga", som Maria beskrev arbetet vid det löpande bandet på sorteringen, eller att de anställs på tillfälliga kontrakt, vilket kvinnorna genomgående är kritiska till. Men kvinnorna riktar inte bara kritik mot villkoren på arbetsplatsen, de har också förslag på vad som skulle kunna göras annorlunda. När jag frågade Molly vad hon skulle förändra på tvätteriet om hon skulle få bestämma svarade hon: "Att vi skulle ha en personalpolitik igen så att man får jobba kvar här. Det skulle förändra mycket."

\section{Noter}

1 Studien inleddes 2019 och är etikprövad. Projektet har fått stöd från Helge Ax:son Johnsons stiftelse och Åke Wibergs stiftelse. Även medel från KK-stiftelsen har bidragit till delar av denna forskning. Jag har dock främst arbetat med det på ofinansierad forskningstid. Tack till Paulina de los Reyes och Mikael Svensson som bidragit med värdefulla kommentarer på en tidigare version av detta kapitel.

2 Eftersom tvätteriet är en industritvätt använder jag ord som industri och fabrik.

3 Av anonymitetsskäl anger jag inte vilket arkiv det gäller och inte heller serienummer. Bland materialet finns bland annat personaltidningar, informationsblad till anställda, fotografier, broschyrer, protokoll (bland annat från en arbetsmiljögrupp, från skyddsronder och från styrelsemöten), minnesanteckningar från möten, jämställdhetsplan, befattningsbeskrivningar och årsbokslut. Det material som har varit av störst intresse för min studie är personaltidningarna och informationsbladen till anställda.

4 Regionarkiv.

5 Regionarkiv.

6 Annonsmaterial. Av anonymitetsskäl anger jag inte var annonsen är publicerad.

7 Siffrorna baseras på en genomgång av de som var anställda vid lönerevisionerna de senaste åren.

8 Den fasta tidsgränsen i LAS, Lagen om anställningsskydd, innebär att för den som varit anställd fler än 360 dagar de senaste tre åren måste arbetsgivaren föra upp namnet på en företrädeslista, som sedan måste följas när anställningar erbjuds. Efter två års total anställning så övergår anställningen i en tillsvidaretjänst. Detta vill en del företag undvika, och "lasar" därför ut all personal innan de når 361 dagar. 
I det avtal som gäller för tvätteriet är det tillåtet att anställa för enstaka dagar, men det finns en begräsning: sex månader efter det första tillfället då en anställning var kortare än en månad, måste följande anställningar gälla minst en månad.

9 Samordningsnummer kan ges till personer som inte är folkbokförda i Sverige och som inte kan få personnummer samt visats i Sverige under kortare tid än ett år (Skatteverket 2020).

10 Under pseudonymen Ruth Cavendish gav hon ut den första utgåvan av boken.

11 De använder även begreppet "exkluderande rasism" (exclusionary racism), som som mer är knutet till att befinna sig i underordnande klasspositioner (Mulinari och Neergaard 2017).

12 Insamlandet av empiri skulle ha avslutats under 2020, men fick avbrytas på grund av coronapandemin. Intervjupersonernas namn är fingerade, och de fick själva välja vilka namn de ville ha. För en person spelade inte namnet någon roll och jag gav henne namnet Maria.

13 Av hänsyn till kvinnornas anonymitet anger jag inte det exakta antalet anställningsår.

14 Länderna anges inte med hänsyn till kvinnornas anonymitet.

15 I intervjucitaten i kapitlet har jag gjort smärre redigering av småord och språk för att underlätta läsbarheten.

16 Jag planerade att under 2020 besöka tvätteriet tillsammans med tolkar som kan några av de många språk som talas på tvätteriet, men på grund av coronapandemin kunde inte detta genomföras.

\section{Referenser}

Acker, J. (2006) "Inequality regimes. Gender, class and race in organizations", Gender \& Society 20(4):441-464.

Behtoui, A. \& Neergaard, A. (2017) "Arbetslivet, etnicitet och 'dom andra". I M. Bengtsson \& T. Berglund (red.) Arbetslivet. Lund: Studentlitteratur.

Berglund, T. (2008) "Klass och arbete". I M. Oskarson, M. Bengtsson \& T. Berglund (red.) En fråga om klass - levnadsförhållanden, livsstil, politik. Malmö: Liber.

Bergman, P. (2009) Kvinna bland stålmän. Lund: Arkiv.

Bonacich, E. (1972) "A theory of ethnic antagonism: The split labor market", American Sociological Review 37(5):547-559.

Bonacich, E., Alimahomed, S. \& Wilson, J.B. (2008) "The racialization of global labor", American Behavioral Scientist 52(3):342-355.

de los Reyes, P. \& Mulinari, D. (2005) Intersektionalitet. Kritiska reflektioner över (o)jämlikhetens landskap. Malmö: Liber.

de los Reyes P. \& Kamali, M. (2005) "Teoretiska reflektioner om makt, integration och strukturell diskriminering". I P. de los Reyes \& M. Kamali (red.) Bortom Vi och Dom. Teoretiska reflektioner om makt, integration och strukturell diskriminering. SOU 2005:41. Stockholm: Fritzes.

Glucksmann, M. (2012) "Reflecting on 'Women on the line': Continuities and change in women's work", International Labour and Working-class History 81:168-173.

Glucksmann, M. (Ruth Cavendish) (1982/2009) Women on the line. London \& New York: Routledge. 
Håkansson, K. \& Isidorsson, T. (2017) "Flexibilitet och nya bemanningsstrategier". I M. Bengtsson \& T. Berglund (red.) Arbetslivet. Lund: Studentlitteratur.

Hörnqvist, M. (2019) "Klasstruktur och arbetets organisering". I Å. Sandberg (red.) Arbete \& välfärd: Ledning, personal och organisationsmodeller i Sverige. Lund: Studentlitteratur.

Kjellberg, A. (2019) "Den svenska partsmodellen utmanad - facket, arbetsgivarna och lönebildningen”. I Å. Sandberg (red.) Arbete \& välfärd: Ledning, personal och organisationsmodeller i Sverige. Lund: Studentlitteratur.

Knocke, W. (1986) Invandrade kvinnor i lönearbete och fack. En studie om kvinnor från fyra länder inom Kommunal-och Fabriksarbetareförbundets avtalsområde. Stockholm: Arbetslivcentrum.

Knocke, W. (1990) "How to be a woman, a worker, and an immigrant", International studies of management and organization 19(4):77-103.

Knocke, W. (1994) "Kön, etnicitet och teknisk utveckling”. I C-U. Schierup \& S. Paulson (red.) Arbetets etniska delning. Studier från en svensk bilfabrik. Stockholm: Carlssons.

Kvist, E. (2006) Stormarknadens nya maktordningar. Från kassörskor och butikschefer till (o)demokratiska arbetslag. Umeå: Umeå universitet.

Larsdotter, F. (2017) Sjuk av jobbet? En klass- och könsanalys av relationen mellan arbete och hälsa. Stockholm: LO.

Marx, K. (1867/1970) Kapitalet. Första boken. Staffanstorp: Bo Cavefors/Clarté.

Miles, R. (1982) Racism and migrant labour. London: Routledge \& Kegan Paul.

Miles, R. (1993) Racism after "race relations". London: Routledge.

Molina, I. (1997) Stadens rasifiering. Etnisk boendesegregation i folkhemmet. Uppsala: Uppsala universitet.

Mulinari, D. \& Neergaard, A. (2004) Den nya svenska arbetarklassen. Rasifierade arbetares kamp inom facket. Umeå: Boréa.

Mulinari D. \& Neergaard, A. (2017) "Theorising Racism: Exploring the Swedish racial regime", Nordic Journal of Migration Research 7(2):88-96.

Mulinari, P. (2007) Maktens fantasier och servicearbetets praktik-arbetsvillkor inom hotell- och restaurangbranschen i Malmö. Linköping: Linköpings universitet.

Mulinari, P. (2019) "Weapons of the poor: Tipping and resistance in precarious times", Economic and Industrial Democracy 40(2):434-451.

Neergaard, A. (2018) Klassamhällets rasifiering $i$ arbetslivet. Stockholm: Katalys.

Ohlsson, B. (2008) Vi som stannade på Volvo - en etnologisk studie om äldre bilindustriarbetares arbetsliv och framtidsplaner. Göteborg: Arkipelag.

Roediger, D.R. (1991/2007) The wages of whiteness. Race and the making of the American working class. London \& New York: Verso.

Räthzel, N., Mulinari, D. \& Tollefsen, A. (2014) Transnational corporations from the standpoint of workers. Houndmills, Basingstoke: Palgrave Macmillan.

Schierup, C-U. (1994) "Etnicitet och arbete - studier från en svensk bilfabrik". I C-U. Schierup \& S. Paulson (red.) Arbetets etniska delning. Studier från en svensk bilfabrik. Stockholm: Carlsson.

Schierup C-U., Paulson, S. \& Ålund, A. (1994) "Den interna arbetsmarknaden etniska skiktningar och dekvalificering." I C-U. Schierup \& S. Paulson (red.) Arbetets etniska delning. Studier från en svensk bilfabrik. Stockholm: Carlssons. 
Skatteverket (2020). https://www.skatteverket.se/privat/skatter/internationellt/ bosattutomlands/samordningsnummer.4.53a97fe91163dfce2da80o01279.html, hämtad 2020-11-03.

Sohl, L. (2014) Att veta sin klass. Kvinnors uppåtgående klassresor i Sverige. Stockholm: Atlas akademi.

Storm, P. (2018) Betydelsen av kön och hudfärg i äldreboendets vardag under olika organisatoriska villkor. Stockholm: Stockholms universitet.

Svensson, M. (2019) Hur klass gör skillnad. Klasspositionens betydelse för rasistiska och negativt särskiljande praktiker. Uppsala: Uppsala universitet.

Sörensdotter, R. (2008) Omsorgsarbete i omvandling. Genus, klass och etnicitet inom hemtjänsten. Göteborg \& Stockholm: Makadam.

Thörnquist, A. (2014) "Mångfaldens retorik och arbetets praktik. Konkurrensutsättning och jämställdhet i hemtjänsten". I P. de los Reyes (red.) Inte bara jämställdhet. Intersektionella perspektiv på hinder och möjligheter i arbetslivet. SOU 2014: 34. Stockholm: Fritzes.

Wallerstein, I. (1997/2004) "Kapitalismens ideologiska spänningar: Universalism kontra rasism och sexism”. I É. Balibar \& I. Wallerstein Ras, nation, klass. Göteborg: Daidalos.

Yazdanpanah, S. (2013) "Den ojämlika jämställdheten - om arbetarkvinnors minskade möjlighet till jämställdhet i Sverige". I O. Fumarola Unsgaard \& K. Thorasdotter (red.) Den feministiska utmaningen. Mot en jämställd arbetsmarknad. Stockholm: Premiss.

\section{Övrigt material}

Annonsmaterial från tvätteriet

Arkivmaterial från regionarkiv 